\title{
EL BÁLSAMO DE LA MISERICORDIA EN LA VIDA SACERDOTAL
}

DOI: https://doi.org/10.52039/seminarios.v62i216.152

ANTONIO ARMENDÁRIZ AlVARAdo*

\section{INTRODUCCIÓN}

Quiero compartir con mis amigos sacerdotes adónde me ha llevado un texto que, además de ser palabra de Dios, siempre ha sido para mí fundamental entre los textos de la Biblia, de la doctrina de la Iglesia y de las diferentes disciplinas de la vida. Ese texto bíblico inspirador es este: «'¿Quién es mi prójimo?’. Jesús respondió: 'Bajaba un hombre de Jerusalén a Jericó... ¿Quién de estos tres te parece que fue prójimo del que cayó en manos de lo salteadores?'. Él dijo: ‘El que practicó misericordia con él'. Jesús contestó: 'Vete y haz tú lo mismo'».

\section{¿Quién no necesita de la misericordia?}

Las reflexiones teológicas que he leído, exhortan al sacerdote ministerial a ser instrumento de la misericordia de Dios para su Pueblo, a los obispos, a los párrocos, a los superiores religiosos, y está bien esa exhortación, motivación, promoción o como le queramos llamar. Se encomienda al ministro, especialmente motivados por el Año de la Misericordia. Yo me pregunto, también el sacerdote, siendo un consagrado, «tomado de entre los hombres y puesto al servicio de los hombres, en lo que se refiere a Dios» (Heb 5,1) necesita de la misericordia de Dios, de una «misericordia encarnada» en su ser de hombre, que lo haga sentir en sí mismo la misericordia que a su vez debe dar a los demás, pero que requiere de la fuerza necesaria para desempeñar con mayor frescura el trabajo que Dios le encomienda en todo aquello que al mismo Dios se refiere.

\section{Aspecto físico del sacerdote}

El sacerdote, siendo hombre, posee una fisiología, un cuerpo que cuando está sano la disposición al servicio pastoral puede ser más adecuado, pero

* Sacerdote Misionero del Espíritu Santo. Licenciado en Administración de empresas y en Teología espiritual. Se ha especializado en acompañamiento y asesoría espiritual, especialmente a sacerdotes. Ha sido director de la Fundación Rougier, en la que se atiende a sacerdotes con problemas. 
también el mismo servicio lo va desgastando, requiriendo ser atendido prudentemente. No podemos negar que, algunas veces, por las ocupaciones ministeriales, el sacerdote descuida su salud, su sueño, su alimentación, su ejercicio físico, su descanso y poco a poco la frescura y el entusiasmo de los primeros años de ordenación se van extinguiendo. ¿Están el pueblo de Dios o la comunidad religiosa atentos a ser instrumento de misericordia en esta parte tan importante de su ministerio? Se muestra esa misericordia de Dios al sacerdote cuando está enfermo, en su dolorosa soledad, cundo experimenta la crisis de su salud en el dolor o el agotamiento de su cuerpo. ¿No necesitará el sacerdote de un buen samaritano que le ofrezca el auxilio, vende las heridas de su agotamiento, de su soledad, de su hambre, de su sueño perdido por tantas preocupaciones pastorales?

\section{Aspecto psicológico del sacerdote}

El joven sacerdote en su entusiasmo, con la fuerza y la energía de su juventud, no midió límites, no fue orientado antes de ponerse a edificar la casa y con altas y bajas llegó a su ordenación, pero una vez pasados los primeros años, meses, semanas, quizá siente que hay lagunas que no cubrió en su desarrollo emocional: afectiva, sexual, física y socialmente ahora parece reclamar los satisfactores que llenen esas necesidades legítimas. Encontrará en su vida ministerial con quien compartir la conciencia de esas deficiencias humanas que lo hacen ir perdiendo el gusto por la oración, la vida sacramental y enfocando su actividad más bien a aspectos administrativos, económicos, de construcción, que ciertamente no son malos, pero que no son esencialmente los de un hombre que ha consagrado su vida a Dios, dándolo todo sin buscar compensaciones, a veces no tan coherentes con su ser de sacerdote. ¿Encontrará en su caminar un buen samaritano que le ofrezca la misericordia de llevarlo a quien pueda vendar las heridas? Las que pudieron dejarle la falta de cariño, de respeto en su niñez y adolescencia, la experiencia que ha guardado en lo profundo de su corazón sin sentir la confianza para compartirlas y por lo mismo se han ido haciendo más punzantes y dolorosas y ahora descubre que posiblemente, nunca debió seguir a Cristo en el sacerdocio.

\section{Aspecto social del sacerdote}

Encontramos en nuestro camino a sacerdotes que sufren de baja autoestima, de miedo a la autoridad, de exagerada timidez para desarrollarse fuera de su ámbito sacramental, seguros y firmes en el confesionario o en el púlpito, preparados para comunicar sus homilías, muy seguros para dar consejos en los sacramentos y, qué bueno que así sea, pero inseguros, medrosos, pero callados ante cualquier acontecimiento que suponga participación social. 
$\mathrm{Y}$, al contrario, sacerdotes demasiado metidos en todo, quieren ser el centro de todo, sienten que todo lo saben, que pueden opinar con maestría en todos los campos del saber: teología, filosofía, administración, economía, política y en realidad cuando esto no es una sencilla opinión en los campos que no domina, sino que habla como quien tiene autoridad, los demás sólo guiñan el ojo y lo siguen escuchando, al fin y al cabo es el padrecito, dice la gente sencilla, pero la no tan sencilla sólo sonríe con cierto sarcasmo. ¿Habrá seglares comprometidos que con honradez, prudencia y valentía le puedan aplicar la corrección fraterna evangélica al sacerdote? Buscando su bien, desde luego. ¿Habrá buenos samaritanos que se atrevan a vendar esas heridas que alejan a los demás del pastor? ¿Permitirá al sacerdote ser curado de esas heridas que, de tenerlas tanto tiempo, ya ni le lastiman, aunque sí lastiman a los que están a su alrededor?

\section{Aspecto espiritual del sacerdote}

¿A qué se debe el desencanto de muchos sacerdotes, de todas las edades? ¿Dónde quedó la frescura del amor primero? (Ap 2). Cuántos jóvenes sacerdotes, a pocos años de ordenados, dicen: «Creo que me equivoqué, añoro una familia, una esposa, unas vacaciones, una profesión». Se cayó en el activismo como consecuencia de los primeros dulces del inicio de la vida pastoral. Todos lo elogiaban por sus homilías, su simpatía, su buena presencia. ¿Y ahora? Los libros de teología y las guías de homilía se empolvan. Improviso, el tiempo no me alcanza. Me atrae poco volver a reunirme con mis compañeros de ordenación, no sigo frecuentando al amigo entrañable que conozco desde el curso introductorio. También él está demasiado ocupado. A mi familia casi no la visito; para qué, cuando lo hago suelen ponerme de mal humor los problemas que me cuentan, que si mi papá con sus achaques, mi mamá con tantas asociaciones religiosas para orar por mi sacerdocio, mi hermano mayor perdió el trabajo, mi hermana anda mal en su matrimonio. Mejor me quedo en casa. Y los valores trascendentes como la oración, el rezo reposado y sabroso del breviario, el diálogo con los colaboradores de la parroquia... Mejor no, traen muchas «broncas» entre ellos, puros chismes. Y no se diga en la línea afectiva.

Creo que ando mal, estoy como desencantado, he empezado, sobre todo los domingos después de las misas, con el pretexto de relajarme, a beber unos «tequilitas», veo televisión hasta altas horas de la noche, tengo derecho a descansar después de tanta friega en el ministerio. Descuelgo el teléfono, ya se han quejado por parte del hospital que han llamado varias veces y el teléfono está ocupado. Bueno, Dios sabe que estoy cansado, fastidiado, enojado.

Cómo realizo la celebración eucarística, cómo atiendo a los grupos parroquiales, cómo es mi relación con mi vicario, si soy párroco, o viceversa, si soy vicario, cuánto respeto y deseos de aprender del pastor me inspira el párroco a ser mejor sacerdote. 
Creo que mi salud no anda bien, padezco gastritis, dice el doctor que mi colesterol y los glicéridos están altos. Un compañero me ha dicho que mi humor está negro, que me ha visto en las juntas de decanato, cuando voy, que siempre estoy de mal humor, mis aportaciones tienen un tinte muy negativo casi siempre, soy criticón, critico a mi obispo, critico a los curas religiosos que van, las religiosas de la escuela, son unas flojas y exigentes. Mi amigo que ha dicho que, así como me di cuenta que necesitaba la ayuda de Dios (misericordia), en mi cuerpo, con la debida atención, debería consultar un psicoterapeuta y nuevamente acudir al que fue mi director espiritual. También me han sugerido que conviva más con mis compañeros sacerdotes, que los busque, ellos me pueden ayudar con su propia experiencia. Que vuelva a ser como en el seminario el líder alegre en la liturgia, en las reflexiones teológicas.

«Señor, ten misericordia de mí, ayúdame para que sepa cuidar mi cuerpo, es templo del Espíritu, pon en mi camino a las personas que me ayuden. Ayúdame, Señor, a clarificar en mi mente qué es lo que tú quieres y a quién debo acudir en ayuda profesional, ya no me soporto ni a mí mismo. Muéstrame tu misericordia para ver con claridad y volver a amar mi sacerdocio como al principio. Dame amigos buenos con quien compartir mis penas y mis alegrías y, si son sacerdotes como yo, mejor, pero sé que antes de pretender conseguir buenos amigos, primero debo serlo. Dame esa gracia. Y, sobre todo, Señor, déjame enamorarme nuevamente de ti. Ayúdame a vivir los sacramentos como lo más hermoso que he recibido de ti. Ayúdame a que nuevamente vuelva a sentirme feliz de proclamar la Palabra con el fuego del principio de mi sacerdocio. En una palabra, Señor, por tu Madre, que es la mía, porque tú me la diste al pie de la cruz». 